\title{
The History Of Trade Relations Of Central Asian Countries With Foreign Countries
}

\author{
Uktam Mansurov \\ Associate Professor, Candidate Of Historical Sciences, Tashkent State Pedagogical University \\ Named After Nizami, Uzbekistan
}

Journal Website:

http://usajournalshub.c

om/index,php/tajssei

Copyright: Original

content from this work

may be used under the

terms of the creative

commons attributes

4.0 licence.

\section{ABSTRACT}

The article describes the history of trade relations of Central Asian countries with foreign countries in ancient and medieval times, the importance of the Great Silk Road, the impact of these relations on political, economic, diplomatic, ethnic and cultural relations. It states that due to diplomatic and trade relations with foreign countries, mutual relations have been established, and the movement of citizens abroad and their entry is based on certain rules. Attention is paid to such factors as the impact of such relations on the socio-political and economic situation in those countries, the specific way of life of the peoples of the region, the way in which diplomatic relations are established. The article focuses on the development of trade relations with foreign countries during the reign of ancient Khorezm, Sogdiana, Parthia and the medieval Hephthalites, the Turkish Khanate, the Arab Caliphate, Amir Temur and the Temurids, the Central Asian khanates, Khiva, Kokand, Bukhara khanates.

\section{KEYWORDS}

Trade, market, commodity, money, exchange, foreign, communication, citizen, state, lifestyle, political, social, cultural, economic, foreign, ancient, medieval.

\section{INTRODUCTION}

If we look at the past, we can see that the formation of the first money circulation, the minting of the first coins, metalworking and metalworking of labor tools further increased labor productivity, created opportunities for trade. This process has accelerated in Central Asia, one of the richest historical and cultural regions of the world. Here, the expansion of markets, the conquest of other territories and the expansion of borders have also created the 
conditions for mutual internal and external struggles. In particular, the specialization of trade by industry, the development of which as a separate economic sector was important for economic development, promoted trade, which was an important factor in the expansion of trade. As a result, due to the development of mutual trade and trade, there will be socio-economic growth in the lives of countries. Undoubtedly, this not only contributes to the development of diplomatic and trade relations with foreign countries, but also affects the socio-political and economic situation in the countries, changing the way of life of the people of the region, the development of diplomatic relations.

\section{METHODS}

The article is based on all social sciences and humanities, including historical objectivity, consistency, historical-comparative analysis, chronological study of historical and social events, reliance on sources and evidence and their validity. Some retrospective-analytical methods of studying the sources were also used in the identification of historical events and phenomena.

\section{CONCLUSIONS}

Historical sources testify that in the ancient countries of Central Asia, as in other parts of the world, the emergence of the first money circulation, the opening of the first markets created the conditions for the emergence and further expansion of trade. This was one of the main factors in the formation of the first statehood in the region. In ancient times, such a process began to take place in the southern regions of Uzbekistan in Sopolli, Jarqotan, Kyzyltepa, Anov, Kozalikir, Afrosiyob, Daratepa, Chust, Dalvarzin and other regions.
If we look at the history of the ancient states of Central Asia, the first state associations, such as ancient Sogdiana, Bactria, Parthia, Khorezm, Ustrushana, established intensive trade, economic and cultural ties with ancient China, India, Iran and Byzantium. Such ties have undoubtedly aroused the interest of foreign merchants, large landowners, rulers, and even researchers in the country.[1]

The natural-geographical location and climatic features of the region testify to the steady development of such types of farming as traditional farming based on artificial irrigation, handicrafts, trade, land tenure, nomadic and semi-nomadic livestock in accordance with the natural conditions of the steppe and desert. This led to an increase in the level of production of the states, the growth of their power, the establishment of regular trade relations. In turn, trade relations have always filled the markets with products, have a positive impact on the lifestyle of the population, as well as created opportunities for the circulation of money, the exchange of money and goods in international trade. In turn, contributed to the development of the tax system. For example, the development of trade in the country has long been associated with the need to produce quality products and sell them abroad. In particular, it is known from history that in the VII-VI centuries BC there were the first markets in Khorezm, Bukhara, Samarkand, and customs posts on the border, and thousands of workers worked on their construction.[2]

Even the ancient Greeks and Romans gave information about the natural-geographical location of Central Asia, the way of life of its inhabitants. This indicates the development of trade and economic relations between the regions in their time. In particular, such ancient data also apply to the ancestors of the Uzbek, Kazakh, Kyrgyz, Turkmen, Karakalpak peoples, 
Sak and Massagets, who lived in the area between the two rivers, the Amudarya and Syrdarya. [3] In the Silk Road trade and among traders in general, the Sogdians took the lead. At that time, silver, Badakhshan rubies, colored glass and glassware, various fruits, cotton, and the pedigree of horses were exported from Central Asia.

In the Middle Ages, the Hephthalites, the Turkish Khanate and the Arab Caliphate ruled in what is now Central Asia, during which time trade relations with Iran, India, China and Syria increased. Most of the products made in Movarounnahr were brought to Samarkand and Bukhara and then spread to other countries. Some small towns also played an important role in domestic and foreign trade. The cities of Jizzakh (Ustrushona) and Uratepa also played an important role in this regard. In particular, the Hephthalite state sought to control the Great Silk Road trade route.

In the Middle Ages, Muslim citizens from major cities in the East, such as Baghdad, Damascus, and Herat, were given certain privileges in collecting customs duties on yams under diplomatic and trade rules on the basis of equal cooperation and peace with foreign countries, a tradition that dates back to the Arab Caliphate. The traveler Ibn Battuta writes that in the Middle Ages mines were brought from Khorasan, rubies, diamonds from India and Sindh, satin from China, rare stones, musk, gold and silver from other countries, among which Muslim merchants were given special privileges, Khorezm had a special place.[4]

According to the partnership, in the past, various goods were exported from Central Asian cities to foreign countries, including wheat, rice, fruits, vegetables, cotton and other products. At the same time, certain categories of traders were given privileges when crossing the Silk Road posts. In particular, no customs duties were levied on people with pajamas. Naturally, the citizens who went on a long journey rested in caravanserais located in the cities of that country. In the villages, such hostels were often visited by khanaqahs.

According to sources, during this period, traders also traded with Khorezm and the Caspian littoral states. The mayors tried to create all the conditions for the merchants. The cities have caravanserais, which are located close to the market. There are also trading posts in the caravanserais, where traders rested in the caravanserai, engaged in trade and commerce, and exchanged goods. Caravanserais were also built on trade routes. In particular, trade relations with Khorezm, East Turkestan, especially China, Khorasan (Ghazna), Nishapur have been established. The population was mainly engaged in handicrafts (pottery, weaving, glassmaking, blacksmithing, jewelry), as well as processing of agricultural and livestock products. Precious stones, copper, iron were mined from the mountains and sold at high prices.

Especially in the Middle Ages and later, the entry and exit of citizens from one state to another by caravans coming for trade was carried out according to certain rules. Under current diplomatic regulations, Central Asian ambassadors have a special label that allows traders to travel to other Muslim countries for political, travel or commercial purposes. For example, during the reign of the Mongols under Genghis Khan, such a label was called "payza"[5]. In particular, the Mongol khan during the reign of the great Hakan Ogedey, that is, in 1229-1241, on the basis of special diplomacy, that is, those who served themselves, went abroad to the occupied countries, and introduced special pies for those 
who knew various information about those countries. This is because traders with this label were able to pass through customs without any barriers in the territories occupied by the Mongols, or they were exempted from taxes when trading in the markets and had a number of other benefits.

In fact, such a special diplomatic label is often given to ambassadors and traders. In some cases, even wealthy officials have entrusted these pajamas to the supreme rulers so that they can move freely from one state to another without any obstacles. The pistachio is made of precious metal (wood, silver) or brass, wooden boards, stamped "Noyon" (so-called district or city ruler). Such payzas were also enjoyed by ambassadors, tax collectors, and they also had certain privileges at the Silk Road posts when entering and leaving the country.[6]

In the Middle Ages, the stations of the Great Silk Road, located on trade routes, were called "yams" (jams). The cost of service for customs officers was borne by the local population. Ambassadors, couriers, and other persons with payzas were able to pass through such trade station stations without any checks. From 1235, according to the Haqqan's (King) decree, the cost of communication services of each yam was borne by the inhabitants of at least 2 districts.[7] Historian Rashididdin also wrote about this. The value of the goods of the merchants in the caravan was also levied on the Silk Road checkpoints of foreigners, depending on whether they came from far or near. The main vehicle was a two-humped Bactrian camel, resistant to hot, cold and desert climates.[8]

Also, during the Mongol rule, in Central Asia, Iran, and the Golden Horde, a special "stamp" was collected from traders for the khan's treasury. As a result of the introduction of this tax, the Mongol rulers benefited greatly. [9] This tax was a heavy burden on the local people, especially the merchants and artisans. Under this tax, each taxpayer was required to pay it within a certain period of time based on his income. During the reign of Amir Temur and the Temurids, this type of tax was preserved by reducing land taxes, but the owner provided a number of other benefits to traders and artisans in the field of trade and handicrafts. The rule of the Chigatay nation was abolished when Amir Temur came to power.

Diplomatic and economic relations between the Central Asian states developed further, especially during the reign of Amir Temur and the Temurids. Well-known scientist I. Muminov emphasizes that the Spanish ambassador De Clavijo Gonzalez also wrote about it. According to the scholar, Gonzalez in his memoirs praised Amir Temur as a great diplomat, ruler and politician. He writes that an important aspect of Amir Temur's domestic policy is the strict discipline at the entrances to the city of Samarkand, the richness and cheapness of the domestic market, as well as its role in foreign trade. [10] In particular, the cities of Turkestan received leather and cloth from Rome and Tatarstan, ironware, dishes, musk ware, dates, olives, the best silk and fabrics from China. There are also rubies, pearls and various other valuables and medicines that are not found anywhere else in the world.[11]

The Timurid state had regular trade relations with China, India, Iran, Russia, the Volga region, and Siberia. The embassy relations of the Timurids played an important role in expanding trade relations with foreign countries. As a local ruler, Amir Temur built trade markets and roads, and multiplied caravanserais. Especially in Samarkand and Bukhara there were markets, choirs, teams, handicraft facilities.[12] 
On both sides of the city streets there were stalls of shops and artisans.

The cities of Samarkand and Bukhara were distinguished by the breadth of trade areas and the presence of specialized markets. The market was also a shopping center and a place for the production of handicrafts. Also in the markets were sold manuscripts books, writing papers, clerks writing applications or letters, money changers also served here. The trade counter (rasta) is named after the goods sold there. There were talks about literature, poetry, science in the markets, and decrees were issued. Eventually, criminals and culprits were punished. Various performances, folk games, public gatherings were organized in the markets.[13] In most cases, the markets are built near mosques, madrasahs and baths.

But despite the fact that at that time the Central Asian states were under the pressure of internal and external struggles, trade never stopped. The main shopping centers in Bukhara, Samarkand, Karshi, Tashkent, Balkh and other major cities have witnessed a significant expansion of trade. Foreign trade relations also developed during that period. In particular, trade with various trade cities of Russia, India, Iran, Kashgar, Turkey. Various agricultural products, handicrafts were mainly exported to foreign markets. Russia was the main buyer of cotton, leather, wool and various fabrics. Central Asian traders also played an important role in bilateral trade between Russia and India. The merchants of Bukhara, in particular, enjoyed special privileges, and the rulers themselves took an active part in foreign trade, sending caravans to foreign countries and receiving financial benefits from them.

International caravan trade through the Great Silk Road played an important role in the development of trade in the country. Many luxurious madrasahs, mausoleums and caravanserais have been built in Samarkand, Bukhara, Shakhrisabz, Shosh and other cities. For example, the unique architectural structure built under the leadership of the ruler Mirz Ulugbek - the observatory embodies the latest achievements of science and technology of that time. [14] In particular, the monetary reform of Mirzo Ulugbek in 1428 was an important event in the development of trade and money circulation, financial policy in the country.

In the Bukhara, Khiva and Kokand khanates of Central Asia, special caravanserais, trade markets, trade counters (rastas), were built for the passage of foreign citizens. There were many covered markets and customs centers here. Abdullah Timi (covered market) was especially popular. Camel caravans were stopped on trade routes, and caravanserais, and cisterns were built for traders to make certain payments and rest. During the khanate period, especially during the Shaybanid period, foreign trade relations with Turkey, Iran, India, Russia and China increased. Anthony Jenkinson, an English tourist who visited Bukhara in 1588, also reported that Bukhara had an annual congress of merchants, with large trade caravans from India, Iran, Balkh, Russia and other countries.

The Emirate of Bukhara and the Khiva Khanate also established diplomatic and trade relations by exchanging ambassadors with the Russian Emperor Ivan Grazniy. For example, walrus teeth, leather products, birds of prey, leather, honey, wax, wooden utensils, glass, velvet, military weapons, metal items, armor were purchased from Moscow. Turkestan exported silk, cotton and woven fabrics, astrakhan leather, carpets, dried fruits, and perfumes to Russia and Siberia. From Tashkent to the Russian market were sold leather goods, 
saddles made of horse skin, arrows, tents, coats, prayer rugs, shoulder pads, bows, paper, grain.[15] By the time of the reign of the Russian Empire, the Silk Road centers in the country were free of customs duties from traders coming from Russia.[16]

In Europe and the East, Uzbek, Tadjik, Kazakh, Kyrgyz, and Turkmen traders were called "Muslim traders." By the end of the last Middle Ages, XVI-XVII centuries, trade relations between Central Asia and Russia became much stronger. It is known that in 1464 the first Russian ambassadors were received by the Timurid Abu Said in Herat. At that time, English wool, fur, leather, wooden utensils, needles, and various pins were brought from Russia to Central Asia. Bilateral trade was important for both parties. While the establishment of trade relations with Bukhara and Khiva protected against possible aggression on Russian territory, customs duties and fees levied on traders in Central Asian cities were much cheaper than in other regions. Second, the Russian government began to view the Bukhara and Khiva khanates as a special transit route with cheap Silk Road points to India in the future.

Although the Great Silk Road lost its significance in the 16 th and early 17 th centuries, the Russian Empire began to pursue its diplomatic and economic colonial goals in the following periods, when the Russian Empire occupied Turkestan. To do this, first of all, it was planned to build railways that regularly supplied raw materials to industrial enterprises in the Russian provinces. It is known that after the construction of railways in Central Asia, they did not carry passengers, so freight transportation by trains was much cheaper and no customs duties were levied on them. In 1881-1886, the Caspian Railway was built from Mikhailovsky Bay to Chorjuy, and in 1888 it was extended to Samarkand. In 1906, the TashkentOrenburg railway was launched. All this led to the further development of trade in the country in the early twentieth century.

In short, the establishment of cooperation between the Central Asian states in trade and diplomatic relations with foreign countries in the past has confirmed the further expansion of trade in urban and rural areas. As a result of the development of foreign trade relations, we have witnessed that the movement of citizens abroad and their entry into the territory of the country is based on certain rules. Such relations have had a positive impact on the sociopolitical situation in those countries, the specific way of life of the people, which in turn has shown the development of diplomatic relations between the states.

\section{REFERENCES}

1. Bichurin N.Ya. Sobranie svedeniy o narodax, obitavshix $v$ Sredney Azii $v$ drevnie vremena.- M.-L., S 226-240.

2. Oblomurodov N. Hazratqulov A. History of Uzbekistan. T., 2011. 116 p.

3. Ibn Battuta. Travelogue. T., 2012. Pages 360-365.

4. Oblomurodov N, Tolipov F. History of taxes in Uzbekistan. T., 2009. p.47.

5. Nemtseva N.B Karavannymi dorogami Golodnoy stepi // Vexi vremën: Almanax. T., 1989. - p. 41-44.

6. Muminov I. The place and role of Amir Temur in the history of Central Asia. T., 1969. 16- b.

7. Pardaev M.X Influence of desert culture on Jizzakh and Bukhara oasis in the early Middle Ages // Social sciences in Uzbekistan. - 1998. - № 4-5. - B. 70.

8. Muminov I. The place and role of Amir Temur in the history of Central Asia. Tashkent., 1969. Pages 7-85. 
9. Qori Niyaziy TN Ulugbek's school of astronomy. M.-L. 1950. 12-110

10. Qoraboev U. Uzbek folk games. - T., 2001. Pages 6-47.

11. Ishquvatov V. Historiography of KokandRussian diplomatic relations. T., 200938 p.

12. Oblomurodov N, Tolipov F. History of taxes in Uzbekistan. T., 2009. Pages 100-106.

13. Oblomurodov N, Hazratkulov A and others. History of Uzbekistan. T., 2011. 213 p

14. Gulyamov G. Srednyaya aziya i Russia: istoki formirovaniya mejgosudarstvennyx otnosheniy. T., 2005 p. 24-63.

15. Tolstov S.P. Osnovnbe voprosy drevneyshey istorii Sredney Azii. VDI. №1, M. 1938.

16. Gulomov Ya. History of irrigation in Khorezm. T., 1959. pp. 68-75.

17. Rasuljanovna, I. N., \& Rakhmonqulovich, K. N. (2020). Trade Relations Between Ancient Bacteria And China On The II-I BC. The American Journal of Social Science and Education Innovations, 2(07), 47-51.

18. Rakhmankulova, Z. (2020). The National Library Of Uzbekistan As A Digital Humanities Center In Uzbekistan. The American Journal of Social Science and Education Innovations, 2(10), 25-33. 